\title{
The Electrokinetic Properties of Some Fungal Spores
}

\author{
By D. J. FISHER AND D. V. RICHMOND \\ Long Ashton Research Station, University of Bristol, Bristol, BS I8 9AF
}

(Accepted for publication 6 March 1969)

\begin{abstract}
SUMMARY
The electrophoretic mobilities of conidia of Alternaria tenuis, Botrytis fabae, Penicillium expansum, Erysiphe graminis, Podosphaera leucotricha and Venturia inaequalis, basidiospores of Stereum purpureum, sporangia and encysted zoospores of Phytophthora infestans were determined in solution at various $\mathrm{pH}$ values. The spores all had characteristic and distinct $\mathrm{pH}$ mobility curves. The zero mobility of $P$. infestans sporangia over the range pH 2 to $I I$ is consistent with a cellulose surface free from ionizable groups. The mobility of basidiospores of $S$. purpureum depended entirely on the presence of carboxyl groups. Chemical and enzymic treatments showed both amino and carboxyl groups on $A$. tenuis and $B$. fabae; phosphate was present in addition on $P$. expansum. The amino groups of $\epsilon$-lysine, histidine and leucine contributed to the surface charge of $B$. fabae; amino acids and tyrosine were detected on $A$. tenuis. The surface of $P$. expansum was proteinfree and the amino groups present were probably derived from a glucosamine or galactosamine polymer. Washed cell walls and intact conidia of $B$. fabae were electrophoretically similar but cell walls of $P$. expansum, unlike normal conidia, were phosphate-free. Mycelial 'protoplasts' of $A$. tenuis and Neurospora crassa and conidial 'protoplasts' of $B$. fabae had pH-mobility curves characteristic of a protein surface.
\end{abstract}

\section{INTRODUCTION}

Douglas, Collins \& Parkinson (I959) showed that the electrophoretic behaviour of asexual spores from four fungal species indicated marked differences in the chemical nature of the spore surfaces. Hannan (196I) studied the effect of chemical treatments on the mobility of Aspergillus niger spores and Somers \& Fisher (1967) investigated in detail the elecktrokinetic properties of conidia, protoplasts and cell walls of Neurospora crassa. The latter workers found amino, carboxyl and phosphate groups to be present on the spore surface, but phosphate groups were absent from washed spore walls. The cationic surface-active fungicide dodine ( $n$-dodecylguanidine acetate)decreased the negative charge on conidia to zero and with increasing concentration gave a positive charge to the spores. The negative charge on cell walls and 'protoplasts' was neutralized at lower fungicide concentrations.

The present work is part of an investigation into the reaction between fungicides and the components of the fungal spore surface. The electrokinetic properties of spores from the following species have been studied to determine the nature of the ionizable surface groups: conidia of Alternaria tenuis Nees, Botrytis fabae Sardiña, Penicillium expansum Link em. Thom, Erysiphe graminis DC. ex Mérat, Podosphaera leucotricha (Ellis \& Everh.) Salm., Venturia inaequalis (Cooke) Wint.; basidiospores of Stereum 
purpureum (Pers. ex Fr.) Fr.; sporangia and encysted zoospores of Phytophthora infestans (Mont.) de Bary. The species include such important plant pathogens as the causal organisms of Potato Blight ( $P$. infestans), Apple Scab ( $V$. inaequalis), Apple Powdery Mildew (P. leucotricha), Oat Mildew (E. graminis), Silver Leaf of fruit trees (S. purpureum) and Chocolate Spot of broad and field beans (B. fabae).

\section{Fungal material}

\section{METHODS}

Conidia from 7-day cultures of Alternaria tenuis, Botrytis fabae and Penicillium expansum were grown and harvested as previously described (Richmond \& Somers, 1963). Sporangia of Phytophthora infestans were obtained from cultures grown on potato slices (var. King Edward) at $18^{\circ}$. Zoospores were liberated by incubating sporangia in distilled water for $\mathrm{I} \mathrm{hr}$ at $2^{\circ}$. Conidia of the following species were washed from naturally infected material: Erysiphe graminis from oat seedlings (var. Black Supreme), Podosphaera leucotricha and Venturia inaequalis from apple leaves (var. Cox). Basidiospores of Stereum purpureum were obtained from fructifications on pear (var. Hendre Huffcap). Protoplasts were prepared from young hyphae of Alternaria tenuis and Neurospora crassa wild type Em 5297a, and from conidia of B. fabae by incubation with Helix pomatia digestive-juice extract (Somers \& Fisher, 1967). The final protoplast suspension was washed and stabilized in $0.58 \mathrm{M}$-sucrose maintained at $\mathrm{pH} 5.6$ with sodium acetate buffer $(I: 0.05)$. Cell walls were obtained by shaking dense spore suspensions at $4^{\circ}$ with ballotini (No. 12) in a Mickle disintegrator (Somers \& Fisher, 1967). The centrifuged cell walls, which retained the shape of intact conidia, were washed ro times with $10 \%(\mathrm{w} / \mathrm{v})$ sucrose, 5 times with $0.9 \%(w / v) ~ \mathrm{NaCl}$ and 5 times with water following the technique of Dyke (I964).

\section{Electrophoretic measurements}

The electrophoretic mobilities of conidia, cell walls and protoplasts were measured by a modification of the technique previously described (Somers \& Fisher, 1967). The laterally mounted rectangular cell was enclosed in a water bath maintained at $25.0 \pm 0.2^{\circ}$. The water-immersion objective was focused on the stationary layer through a closely fitting rubber sheet. Washed human erythrocytes in 0.067-M phosphate buffer ( $\mathrm{pH} \mathrm{7.35)}$ were used to calibrate the apparatus (Gittens \& James, 1960). The conductivity of the buffered suspensions was measured at $25^{\circ}$, on a WayneKerr B22I bridge. Movement was timed over $180 \mu$ in both directions (current reversal) and each mean mobility was obtained from at least 20 observations: the standard error of the mean was less than $4 \%$. Electrophoretic measurements were made on conidia, cell walls and protoplasts ( $\mathrm{I}$ million $/ \mathrm{ml}$.) which had been washed twice with the appropriate buffer before suspension in $\mathrm{HCl}+\mathrm{NaCl}$ or barbiturate+ acetate buffer (I:0.05) of the required pH (Gittens \& James, 1960). Protoplasts were measured in buffer containing $0.58 \mathrm{M}$-sucrose.

\section{Treatments to modify surface groups}

Alkaline phosphatase: (EC 3.I.3.I). Washed conidia and cell walls were suspended in barbiturate buffer ( $\mathrm{pH} 7 \cdot 9, I: 0 \cdot 02)$ containing $5 \mu \mathrm{g}$. alkaline phosphatase $/ \mathrm{ml}$. for I hr at $37^{\circ}$ (Hill, James \& Maxted, 1963).

I-Fluoro-2,4-dinitrobenzene $(F D N B)$. Conidia and cell walls were washed 3 times in 
phosphate buffer ( $\mathrm{pH} 7 \cdot 0, I: 0 \cdot 05)$ then suspended in an $0.1 \%$ (v/v) ethanolic FDNB solution containing $0.9 \%(\mathrm{w} / \mathrm{v}) \mathrm{NaHCO}_{3}$ for $5 \mathrm{hr}$ (Gittens \& James, 1963). The sediment was washed 5 times with ethanol before washing with the final buffer solution.

p-Toluenesulphonyl chloride (PTSC). Washed conidia in barbiturate buffer $(\mathrm{pH} 7 \cdot 0$, I:0.05) were shaken with $50 \mathrm{mg}$. PTSC for $24 \mathrm{hr}$ at room temperature (Gittens \& James, 1963).

Diazomethane $(D A M)$. Washed conidia and cell walls were methylated as previously described (Somers \& Fisher, 1967). Conidia were washed once with phosphate buffer $(\mathrm{pH} 7.0)$ and twice with $\mathrm{HCl}(0.05 \mathrm{M})$ before methylation.

\section{Identification of $\mathrm{N}$-terminal amino acid groups}

Conidia after treatment with FDNB were hydrolysed in a sealed tube at $105^{\circ}$ for I6 hr in the presence of $5.7 \mathrm{~N}-\mathrm{HCl}$. After extraction (Biserte, Holleman, HollemanDehove \& Sautière, I960) the DNP-amino acids were separated by thin layer chromatography (Pataki, 1967).

\section{Lipid determination}

Total lipid was determined by extraction of dried cell walls (in vacuo over $\mathrm{P}_{2} \mathrm{O}_{5}$ ) with hot chloroform + methanol $(2+I, v / v)$ followed by hot ether.

\section{RESULTS}

Electrophoretic properties of fungal conidia. Sporangia of Phytophthora infestans had zero mobility over the whole $\mathrm{pH}$ range (Fig. I), indicating the absence of surface ionogenic groups. Zoospores of $P$. infestans (Fig. I) and basidiospores of Stereum purpureum (Fig. 2) showed no positive mobility at low $\mathrm{pH}$, suggesting a preponderance of acidic surface groups. The $\mathrm{pH}$-mobility curve of $S$. purpureum is characteristic of a simple carboxyl surface (Hill et al. 1963). Cells treated with alkaline phosphatase had a similar mobility to untreated spores, confirming the absence of phosphate groups. Treatment with DAM (Fig. 2) decreased the mobility to zero between $\mathrm{pH} 2$ and 5, suggesting that only carboxyl groups contribute to the surface charge. Above $\mathrm{pH} 7$, however, the mobility did not return to its original value after hydrolysis of the methyl esters. DAM treatment may block other surface groups. Suspension in $0.05 \mathrm{M}-\mathrm{HCl}$ followed by ether + ethanol and ethanol as required for the chemical treatments did not cause irreversible changes to any of the spore surfaces. After resuspension in $\mathrm{pH} 7$ buffer mobilities were the same as normal control spores.

The $\mathrm{pH} /$ mobility curves of Podosphaera leucotricha, Erysiphe graminis, Venturia inaequalis, Alternaria tenuis and Botrytis fabae (Fig. 2 to 5) are characteristic of mixed aminocarboxyl surfaces (James \& List, I966).

Treatment of Alternaria tenuis and Botrytis fabae (Fig. 4 and 5) with FDNB decreased the positive mobility at low $\mathrm{pH}$ and removed the inflexion at $\mathrm{pH} 10 \circ 0$, confirming the presence of amino groups on the untreated surface. Hydrolysis of FDNB-treated $B$. fabae conidia followed by chromatography revealed spots corresponding to the DNP derivatives of $\epsilon$-lysine, histidine, leucine and an unidentified compound; $\boldsymbol{A}$. tenuis conidia revealed, in addition, a spot corresponding to DNPtyrosine. The unidentified compound in $A$. tenuis and $B$. fabae had a similar $R_{F}$ value 
to the DNP derivatives of D-glucosamine and D-galactosamine, and might have been derived from a glucosamine or galactosamine polymer in the cell wall.

Cell walls of Botrytis fabae gave a $\mathrm{pH} / \mathrm{mobility}$ curve of the same general shape and with the same isopotential point $(3 \cdot 8)$ as intact conidia. Conidia of Alternaria tenuis,

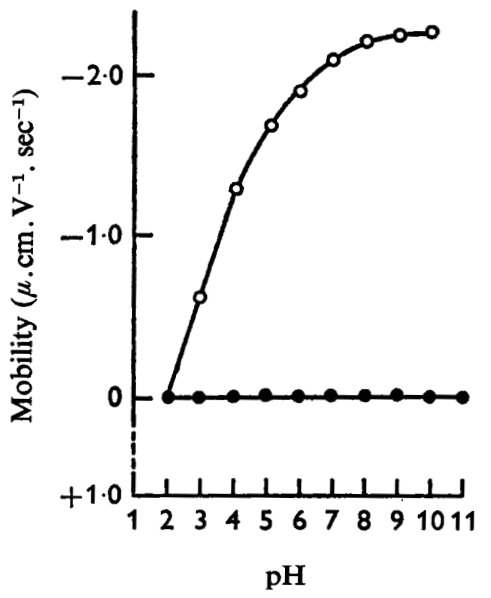

Fig. I

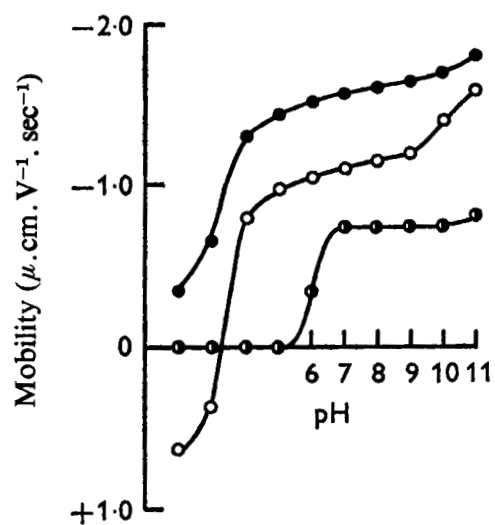

Fig. 2

Fig. I. pH/mobility curves of Phytophthora infestans sporangia, $\mathrm{O}-\mathrm{O}$.

Fig. 2. $\mathrm{pH} / \mathrm{mobility}$ curves of conidia of Venturia inaequalis, $\bigcirc-\bigcirc$; basidiospores of Stereum purpureum, - ; and DAM-treated basidiospores of S. purpureum,

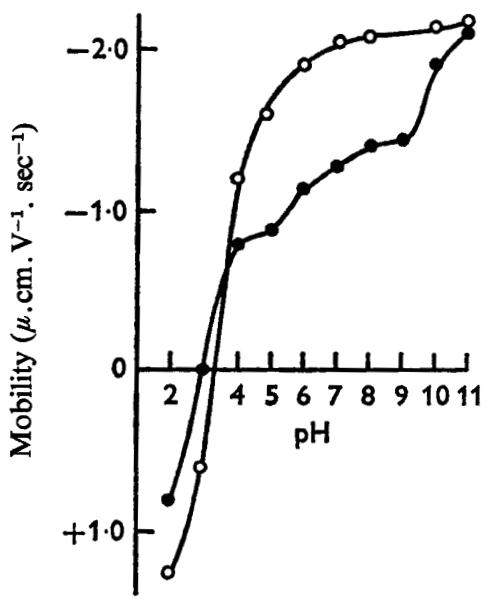

Fig. 3. $\mathrm{pH} /$ mobility curves of conidia of Podosphaera leucotricha, Erysiphe graminis, $\mathrm{O}-\mathrm{O}$.

unlike the other spores examined, are multicellular; this made it difficult to prepare clean cell walls which still retained the shape of intact conidia. Methylation of A. tenuis conidia (Fig. 4) and B. fabae walls (Fig. 5) with DAM decreased the negative mobility by removing the charge on the carboxyl groups; positive mobilities below 
$6 \cdot 0$ are due to the remaining amino groups. The decrease in positive mobility of DAMtreated cells below $\mathrm{pH} 4$ may be due to some interaction with amino groups. Mobilities were unaffected by treatment with alkaline phosphatase. Only small increases in the mobility of conidia or cell walls occurred in the presence of sodium dodecyl sulphate (SDS), showing the absence of appreciable amounts of surface lipid (Table I). The

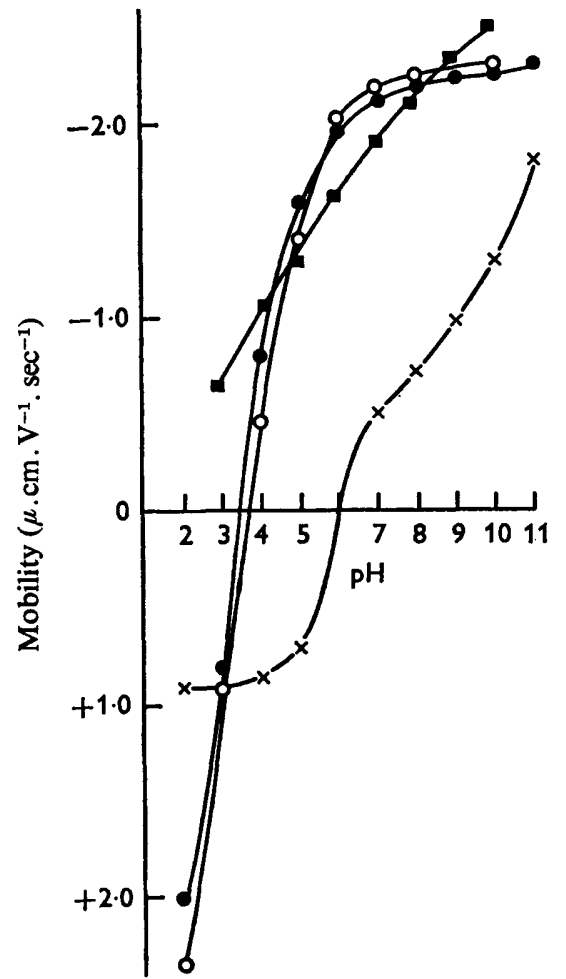

Fig. 4

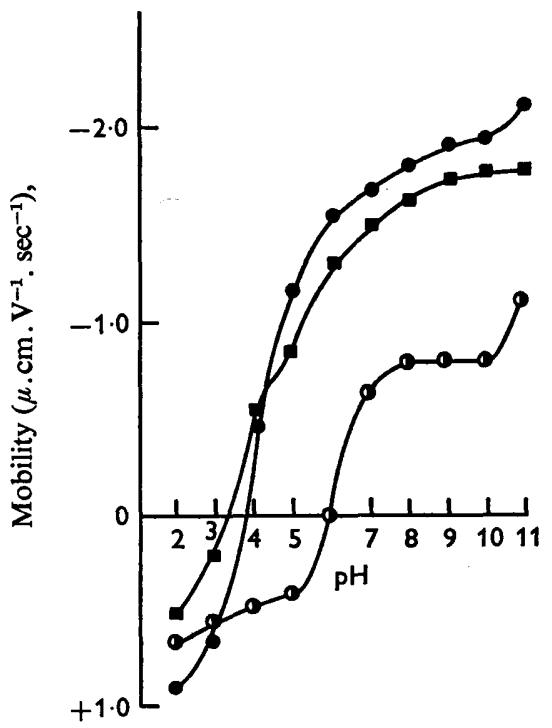

Fig. 5

Fig. 4. pH/mobility curves of conidia of Alternaria tenuis. Untreated, treated, $\mathrm{O}-\mathrm{O}$; FDNB-treated, $\mathrm{a-}$; DAM-treated, $x-x$.

Fig. 5. pH/mobility curves of Botrytis fabae. Untreated conidia, -O; FDNB-treated conidia, -n; DAM-treated cell walls, $1-0$.

Table I. Effect of sodium dodecyl sulphate (SDS) on the electrophoretic mobility of conidia and washed cell walls

Suspension medium: phosphate buffer solution (pH 7.0, I: 0.01)

\begin{tabular}{|c|c|c|c|}
\hline \multicolumn{4}{|c|}{ SDS concentration (M) } \\
\hline 0 & $10^{-6}$ & $10^{-5}$ & $10^{-4}$ \\
\hline \multicolumn{4}{|c|}{ Electrophoretic mobility $\mu . \mathrm{cm} . \mathrm{V}^{-1} . \mathrm{sec}^{-1}$} \\
\hline$-2 \cdot 62$ & -3.02 & -3.04 & $-3 \cdot 26$ \\
\hline$-I \cdot 4 I$ & $-I \cdot 45$ & $-I \cdot 49$ & $-I \cdot 53$ \\
\hline$-1 \cdot 54$ & $-I \cdot 80$ & $-I \cdot 76$ & $-I \cdot 76$ \\
\hline$-I \cdot 52$ & $-1 \cdot 42$ & $-1 \cdot 57$ & $-I \cdot 56$ \\
\hline
\end{tabular}

A. tenuis (conidia)

B. fabae (walls)

$P$. expansum (conidia)

$P$. expansum (walls)

$-1 \cdot 54$

$-I \cdot 42$

$-1 \cdot 76$
$-I \cdot 57$

$-1 \cdot 56$ 
total lipid content of cell walls on a dry weight basis was $4.6 \%$ for $A$. tenuis and $6.6 \%$ for $B$. fabae. These figures are much lower than the value of $14 \%$ reported for Neurospora crassa (Somers \& Fisher, 1967).

The $\mathrm{pH} / \mathrm{mobility}$ curve for Penicillium expansum (Fig. 6) with an isopotential point at $\mathrm{pH} 2.0$ suggests the presence of highly acidic phosphate groups; treatment with alkaline phosphatase (Fig. 6) revealed an underlying amino-carboxyl surface with an

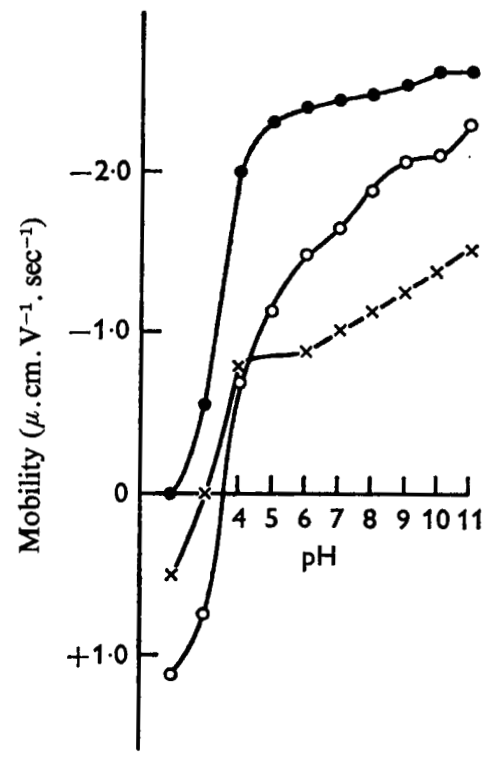

Fig. 6

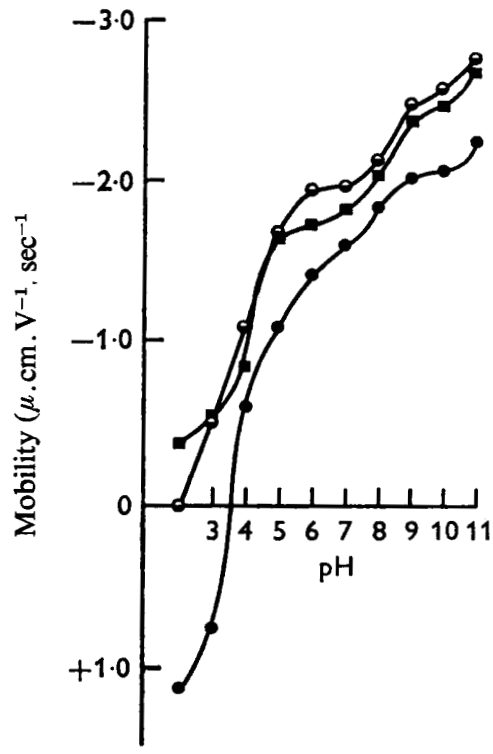

Fig. 7

Fig. 6. pH/mobility curves of conidia of Penicillium expansum. Untreated, tase-treated, $\mathrm{O}-\mathrm{O}$; DAM-treated, $x-x$.

Fig. 7. pH/mobility curves of washed conidia of Pencillium expansum, Untreated, -0; FDNB-treated, $\mathbf{-}-\mathbf{-}$; PTSC-treated, $\bullet-\ominus$.

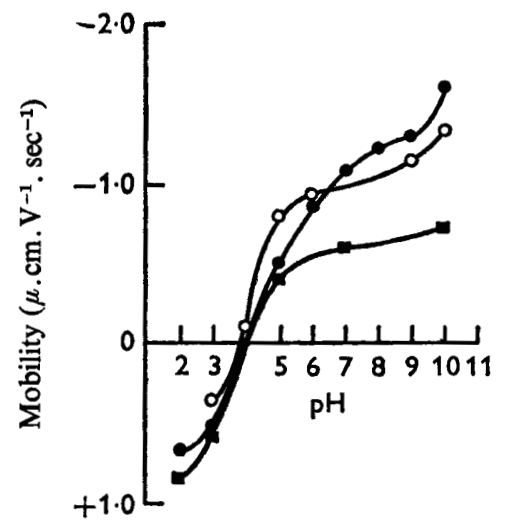

Fig. 8. pH/mobility curves of fungal protoplasts. Hyphal protoplasts of Neurospora crassa, ; hyphal protoplasts of Alternaria tenuis, $-\mathbf{m}$; conidial protoplasts of Botrytis fabae, $\bigcirc-\bigcirc$. 
isopotential point of 3.5 similar to untreated Alternaria tenuis and Botrytis fabae (Fig. 4 and 5). Additional evidence for the presence of phosphate groups on intact $P$. expansum conidia was provided by the decrease in mobility at $\mathrm{pH} 7$ in the presence of $0.0 \mathrm{I} \mathrm{M}-\mathrm{Ca}^{2+}$ from $-2 \cdot 40$ to $-\mathrm{I} \cdot 60 \mu \cdot \mathrm{cm} \cdot \mathrm{V}^{-1} \cdot \mathrm{sec}^{-1}$. The washing technique of Dyke (1964), when applied to intact conidia of $P$. expansum (Fig. 7), was as effective as alkaline phosphatase in removing phosphate groups, but extraction with chloroform + methanol $(2+I, v / v)$ had no effect on the isopotential point, showing that the phosphate was not present as phospholipid. Indeed, the total lipid content of cell walls was only $\mathrm{I} \cdot \mathrm{I} \%$ on a dry weight basis, and mobility measurements in the presence of SDS (Table I) showed that none of this was present on the surface of either intact conidia or washed cell walls.

Conidia of Penicillium expansum treated with DAM (Fig. 6) showed decreased negative mobility due to removal of the charge on the carboxyl groups; after hydrolysis of the methyl ester the mobility was still lower than that of untreated conidia, suggesting that DAM treatment had some blocking action on the amino groups. Interpretation of the $\mathrm{pH} / \mathrm{mobility}$ curve obtained from FDNB-treated conidia was complicated by the simultaneous removal of some of the labile phosphate component. However, when conidia, washed free of phosphate, were treated with FDNB (Fig. 7) the negative mobility was increased, confirming the presence of amino groups. The inflexion at pH 7 to 8 was not due to secondary amino groups, as it was still present when washed conidia were treated with PTSC (Fig. 7), a reagent which reacts with both primary and secondary amines (Gittens \& James, 1963).

Hydrolysis of FDNB-treated conidia followed by chromatography revealed one spot with the same $R_{\boldsymbol{F}}$ value as the unidentified compound found in Alternaria tenuis and Botrytis fabae. No spots corresponding to DNP-amino acids were produced, indicating a probable absence of surface protein.

Electrophoretic properties of protoplasts. The $\mathrm{pH} / \mathrm{mobility}$ curves of protoplasts stabilized in $0.58 \mathrm{M}$-sucrose from mycelium of Neurospora crassa and Alternaria tenuis and from conidia of Botrytis fabae (Fig. 8) have isopotential points (3.9 to 4.0 ) typical of a protein surface. (Protoplasts from B. fabae represent only a part of the cell contents, being liberated from the germ tube of germinating conidia by constriction of portions of the protoplasm.)

\section{DISCUSSION}

All the fungal spores examined have characteristic and distinct electrophoretic behaviours. The sigmoid pH-mobility curves given by protoplasts of Alternaria tenuis, Botrytis fabae and Neurospora crassa, and by conidia of A. tenuis, B. fabae, Erysiphe graminis and Podosphaera leucotricha are typical of amino-carboxyl surfaces. Conidia of Penicillium expansum, Stereum purpureum and encysted zoospores of Phytophthora infestans show no positive mobility at low $\mathrm{pH}$, indicating a preponderance of acidic surface groups. Sporangia of $\boldsymbol{P}$. infestans are unusual in having zero mobility over the whole $\mathrm{pH}$ range and must be completely lacking in surface ionizable groups. Clean $B$. fabae cell walls are electrophoretically similar to intact conidia but $P$. expansum walls are quite distinct from $P$. expansum conidia: the washing technique removed phosphate groups from $P$. expansum conidia to reveal an underlying amino + carboxyl surface. Chemical treatment of $A$. tenuis and $B$. fabae has shown phosphate and lipid 
to be absent from the surface and confirmed the presence of amino and carboxyl groups.

The amino groups on the spore surfaces are probably a part of the protein components of the cell wall (Aronson, 1965; Manocha \& Colvin, 1967), although aminopolysaccharides (Harold, 1962) may also be present. Carboxyl groups may derive from proteins, polysaccharides (Applegarth, 1967) or uronic acids (Mitchell \& Scurfield, 1967). Somers \& Fisher (1967) found $\epsilon$-lysine and histidine on the surface of Neurospora crassa conidia and we have found, in addition, leucine on Botrytis fabae, and leucine and tyrosine on Alternaria tenuis. The high positive mobility of $A$. tenuis at low $\mathrm{pH}$ together with the negative mobility after treatment with FDNB suggests that $A$. tenuis has a higher proportion of surface amino groups than $B$. fabae.

The surface of Penicillium expansum resembles that of Neurospora crassa (Somers \& Fisher, 1967) in having easily removable phosphate groups but differs in having no surface lipid. This is reflected in the much lower total lipid content of cell walls of $P$. expansum (I-I \%) compared with $14 \%$ reported for $N$. crassa by Somers \& Fisher (1967). Although no DNP-amino acids were detected in acid hydrolysates from FDNB-treated conidia an unidentified compound was found which could have been the DNP-derivative of glucosamine or galactosamine. This suggests that the surface is protein free but may contain polyglucosamines or polygalactosamines. Harold (1962) has shown that inorganic polyphosphate can bind to protein and polygalactosamine receptor sites on the outer surface of $N$. crassa hyphae: the phosphate groups on $P$. expansum conidia may be bound in a similar way. The observation of Hess, Sassen \& Remsen (1968) that a very thin layer is present on the outside of conidia of some Penicillium species when examined by carbon replica techniques may also be relevant here.

As the only ionized groups on Stereum purpureum are carboxyl the surface must be protein-free and probably consists entirely of carbohydrate. The absence of ionogenic groups from sporangia of Phytophthora infestans is consistent with the work of Chapman \& Vujičic (1965), who showed that young sporangia of Phytophthora erythroseptica have a structureless, electron-transparent outer layer consisting probably of cellulose.

The protein-like $\mathrm{pH} / \mathrm{mobility}$ curves of the fungal protoplasts are in agreement with the lipoprotein constitution of fungal cytoplasmic membranes (Villanueva, I966). The curves are similar to those reported for rat liver nuclei by Vassar, Seaman, Dunn \& Kanke (1967) and bacterial protoplasts by James, Hill \& Maxted (1965) in conformity with the unit membrane theory (Robertson, 1959).

The water-repellent properties of Penicillium conidia have been attributed to the presence of ether-soluble cyclic peptides on the spore surface (Bertaud, Morice, Russell \& Taylor, 1963) or to the characteristic 'rodlets' which may consist of cutin or sporopollenin detected on the surface of freeze-etched conidia by Hess et al. (I968). The small amount of material soluble in chloroform + methanol in cell walls and the absence of surface lipid suggest that the water-repellent properties are not due to lipids or cyclic peptides. Further studies in conjunction with chemical treatments are required to elucidate the problem. Powdery mildew conidia are also water-repellent and differ from spores of other fungi in their resistance to desiccation (Yarwood, 1936) furthermore spore germination is usually impaired by wetting (Zaracovitis, 1964). McKeen, Mitchell \& Smith (1967), in a study of the Erysiphe cichoracearum 
conidium, considered that the impervious outer layer of the spore played an important role in the action of water and fungicides on mildew conidia. The $\mathrm{pH}$-mobility curves of Podosphaera leucotricha and Erysiphe graminis do not account for the characteristic physical properties of powdery mildew conidia: unionized compounds may be responsible for the non-wettable nature of these spores.

Fungal spores frequently have a specialized and complex morphology which differs considerably from the vegetative cells. Electron microscopic studies of germinating spores have shown that the germ tube wall may be continuous with either the inner (Remsen, Hess \& Sassen, 1967), or the outer (Manocha \& Shaw, 1967) layer of the spore wall, or an entirely new wall may be formed (Hawker, 1966). Several detailed studies have been made of the chemical composition of hyphal cell walls (Aronson, 1965; Rogers \& Perkins, 1968), but less attention has been paid to the spore wall, although Horikoshi \& Iida (1964) have compared the composition of hyphal and conidial walls of Aspergillus oryzae and detailed studies have been made of the chemical structure of the cell wall of Mucor rouxii at different stages of development (Bartnicki-Garcia \& Nickerson, 1962; Bartnicki-Garcia \& Reyes, 1964; BartnickiGarcia \& Reyes, 1968). Spore walls and hyphal walls of $A$. oryzae were qualitatively identical but the composition of spore walls of $M$. rouxii was markedly different from vegetative cell walls. Differences in cell wall composition may explain why fungal spores differ in their susceptibility to fungicides and why some fungicides are more effective against spores than mycelium, while, with others, the reverse is true (Kreutzer, 1963). The physical properties of the spore surface will influence dispersion by air, water or animals (Gregory, 1966); the chemical composition may modify toxicant action. Studies of the fungal spore surface may make some contribution to an understanding both of fungal ecology and of the mechanisms of the selective toxicity of compounds to spores of different fungal species as well as to spores and mycelium of the same species.

We are indebted to Dr E. C. Hislop for providing some of the fungal cultures, and to Dr R. C. Codner of the University of Bath for helpful discussions.

\section{REFERENCES}

Applegarth, D. A. (1967). The cell wall of Penicillium notatum. Archs Biochem. Biophys, 120, 471. Aronson, J. M. (1965). The cell wall. In The Fungi. Ed. by G. C. Ainsworth and A. S. Sussman, vol. I, p. 49. New York: Academic Press.

BARTNICKI-GARCIA, S. \& NiCKerson, W. J. (1962). Isolation, composition and structure of cell walls of filamentous and yeast-like forms of Mucor rouxii. Biochim. biophys. Acta 58, 102.

Bartnicki-Garcia, S. \& ReYes, E. (1964). Chemistry of spore wall differentiation in Mucor rouxii. Archs Biochem. Biophys. 108, 125.

Bartnicki-Garcia, S. \& ReYes, E. (1968). Chemical composition of sporangiophore walls of Mucor rouxii. Biochim. biophys. Acta $165,32$.

Bertaud, W. S., Morice, I. M., Russell, D. W. \& Taylor, A. (1963). The spore surface of Pithomyces chartarum. J. gen. Microbiol. 32, 385.

Biserte, G., Holleman, J. W., Holleman-Dehove, J. \& Sautière, P. (1960). Paper chromatography of dinitrophenylamino acids. Chromat. Rev. 2, 59.

Chapman, J. A. \& VuJčić, R. (1965). The fine structure of Phytophthora erythroseptica. Pethyb. J. gen. Microbiol. 4I, 275.

Douglas, H. W., Collins, A. E. \& Parkinson, D. (1959). Electric charge and other surface properties of some fungal spores. Biochim. biophys. Acta 33, 535 . 
DYKE, K. G. H. (1964). The chemical composition of the cell wall of the yeast Nadsonia elongata. Biochim. biophys. Acta 82, 374.

GITTENS, G. J. \& JAMES, A. M. (1960). An improved microelectrophoresis apparatus and technique for studying biological cell surfaces. Analyt. Biochem. r, 478 .

GitTENS, G. J. \& JAMES, A. M. (1963). Some physical investigations of the behaviour of bacterial surfaces. VI. Chemical modification of surface components. Biochim. biophys. Acta 66, 237.

Gregory, P. H. (1966). Dispersal. In The Fungi. Ed. by G. C. Ainsworth and A. S. Sussman, vol. 2, p. 709. New York: Academic Press.

Hannan, P. J. (196I). Electrophoretic properties of spores of Aspergillus niger. Appl. Microbiol. 9, II3.

HAROLD, F. M. (1962). Binding of inorganic polyphosphate to the cell wall of Neurospora crassa. Biochim. biophys. Acta 57, 59.

HAWker, L. E. (1966). Germination: morphological and anatomical changes. In The Fungus Spore. Ed. by M. F. Madelin, p. 15I. London: Butterworth.

Hess, W. M., SAssen, M. M. A. \& Remsen, C. C. (1968). Surface characteristics of Penicillium conidia. Mycologia. 6o, 290.

HiLl, M. J., JAMES, A. M. \& MAXTED, W. R. (1963). Some physical investigations of the behaviour of bacterial surfaces. IX. Studies on the streptococcal cell wall. Biochim. biophys. Acta 75, 402.

HorIKosH, K. \& IDA, S. (1964). Studies of the spore coats of fungi. I. Isolation and composition of the spore coats of Aspergillus oryzae. Biochim. biophys. Acta 83, 197.

JAMES, A. M. \& LIST, C. F. (1966). Some physical investigations of the behaviour of bacterial surfaces. XII. The effect of fimbriae on the electrophoretic mobility of some capsular and non-capsular bacteria of the coli-aerogenes group. Biochim. biophys. Acta II2, 307.

JAMES, A. M., HIIL, M. J. \& MAXTED, W. R. (1965). A comparative study of the bacterial cell wall, protoplast membrane and L-form envelope of Streptococcus pyogenes. Antonie van Leeuwenhoek 3r, 423.

KreUtZer, W. A. (1963). Selective toxicity of chemicals to soil microorganisms. A. Rev. Phytopathol. I, IOI.

MANOCHA, M. S. \& Colvin, J. R. (1967). Structure and composition of the cell wall of Neurospora crassa. J. Bact. 94, 202.

MaNocha, M. S. \& SHAW, M. (1967). Electron microscopy of uredospores of Melampsora lini and of rust-infected flax. Can. J. Bot. 45, 1575 .

MCKeEn, W. E., Mrtchell, N. \& SMith, R. (1967). The Erysiphe cichoracearum conidium. Can. J. Bot. 45, 1489.

MrTChell, A. J. \& SCURField, G. (1967). Composition of extracted fungal cell walls as indicated by infrared spectroscopy. Archs Biochem. Biophys. 120, 628.

Pataki, G. (1967). Thin-layer chromatography of amino acids. Chromat. Rev. 9, 23.

Remsen, C. C., Hess, W. M. \& Sassen, M. A. (1967). Fine structure of germinating Penicillium megasporum conidia. Protoplasma 64, 439.

Richmond, D. V. \& Somers, E. (1963). Studies on the fungitoxicity of captan. III. Relation between the sulphydryl content of fungal spores and their uptake of captan. Ann. appl. Biol. 52, 327.

RoBertson, J. D. (1959). The ultrastructure of cell membranes and their derivatives. Biochem. Soc. Symp. 16, 3.

Rogers, H. J. \& Perkins, H. R. (1968). Cell Walls and Membranes. London: Spon.

SOMERS, E. \& FISHER, D. J. (1967). Effect of dodine acetate on the electrophoretic mobility of Neurospora crassa conidia. J. gen. Microbiol. 48, 147.

Vassar, P. S., Seaman, G. V. F., Dunn, W. L. \& Kanke, L. (1967). Electrokinetic properties of nuclear surfaces. A comparison of nuclei from normal and regenerating rat liver. Biochim. biophys. Acta 135, 218.

Villanueva, J. R. (1966). Protoplasts of fungi. In The Fungi, ed. by G. C. Ainsworth and A.S. Sussman, vol. 2, p. 3. New York: Academic Press.

YARWOOD, C. E. (1936). The tolerance of Erysiphe polygoni and certain other powdery mildews to low humidity. Phytopathology 26, 845 .

ZaRACOVIrIs, C. (1964). Factors in testing fungicides against powdery mildews. The germination of the conidia in vitro. Annls Inst. phytopath. Benaki 6, 73. 